\title{
Interconnection between Achieved Level of Return on Equity and Evaluation Scale of the Kralicek'S Model
}

\author{
Michal Kuběnka \\ Institute of Business Economics and Administration, University of Pardubice, Czech Republic
}

\begin{abstract}
A large number of diagnostic and predictive models exists using different or no statistical methodology. Often, diagnostic and predictive models differ in focus on branch of company, size of company, tradability of shares, country of usage, and focus on maturity of the market environment. Many of the models are widely used, however, their explanatory power is not known. Good examples of these models are those used in banks in the process of credit worthiness assessment. Some of them are created based on the Q-Test model. However, not only banks need to check the financial situation of companies but also basic users like suppliers, customers and other business partners. This article deals with Kralicek's Q-Test which is one of the well-known financial diagnostic models in Europe including the Czech Republic. Its five grade rating scale reveals little about the level of prosperity of analysed companies. An assumption exists that grade 1 means excellent financial health. However what exactly does it mean? Can it be assumed that this means a negligible to zero probability of bankruptcy and simultaneously a sufficient or a high profitability? The question is what is the level of prosperity connected with the grades achieved on the Q-Test evaluation scale from 1 to 5 . The prosperity of the company is uniquely linked to the return on equity. Another question is whether the QTest is able to express a level of prosperity and not only a level of creditworthiness of companies. That is why the research based on analysis of dataset of 1504 Czech companies was carried out. Following the research a scale was made of achieved return on equity (ROE). ROE levels are expressed by the following: implicit cost of equity $\left(r_{e}\right)$, riskfree rate $\left(\mathrm{r}_{\mathrm{f}}\right)$, positive ROE, negative ROE and negative equity (or insolvency). The researched found that the Q-Test's informative value is comparable to the predictive models based on statistic techniques.
\end{abstract}

Keywords: Q-test, Return on equity, Prosperity, Financial health, Rating, Financial analysis

\section{Introduction}

Financial models can be divided in the category of diagnostic and predictive models. Alternatively they can be classified into category bankruptcy models and prosperity models. The bankruptcy models accuracy is known just during their creation using statistical methods and sample of companies for testing. A review of the literature indicates that probably the first researcher using ratio analysis to compare companies that had failed and companies that had not was P. J. Fitzpatrick (Fitzpatrick, 1931). His model consists of 13 financial ratios to indicate failure using uni-variate analysis for creation. However, prediction power was not significant.

Further progress was when W. Beaver (Beaver, 1966) used Univariate Logistic Regression to creation of model to predict financial distress. His innovation was also in using of ratios associated with cash flows. He worked with 30 financial ratios that he chose as the best indicators of a company's financial distress. These indicators can be divided into six groups:

- Ratios related to cash flow,

- ratio of liabilities to total assets,

- ratio of liquid assets to total assets,

- ratio of liquid assets to current liabilities, 
Michal Kuběnka

Institute of Business Economics and Administration University of Pardubice, Pardubice City, Czech Republic

- the ratios of turnover,

- ratios of net profit.

Table 1: Historical overview of model's creation

\begin{tabular}{|c|c|c|}
\hline Models used to predict financial distress & Researcher(s) & Year \\
\hline \multirow{5}{*}{ Univariate models } & Fitzpatrick & 1931 \\
\hline & Ransmer and Foster & 1931 \\
\hline & Merwin & 1942 \\
\hline & Walter & 1957 \\
\hline & Beaver & 1966 \\
\hline \multirow{15}{*}{$\begin{array}{c}\text { Multivariate Discriminant } \\
\text { Analysis (MDA) }\end{array}$} & Altman & 1968 \\
\hline & Deakin & 1972 \\
\hline & Edmister & 1972 \\
\hline & Blum & 1974 \\
\hline & Moyer & 1977 \\
\hline & Altman, Halderman, and Narayanan & 1977 \\
\hline & Altman & 1983 \\
\hline & Booth & 1983 \\
\hline & Fulmer, Moon, Gavin, and Erwin & 1984 \\
\hline & Casey and Bartczak & 1985 \\
\hline & Lawrence and Bear & 1986 \\
\hline & Aziz, Emanuel, and Lawson & 1988 \\
\hline & Altman & 1993 \\
\hline & Altman & 2000 \\
\hline & Grice and Ingram & 2001 \\
\hline \multirow{12}{*}{ Logit and Probit Analysis } & Martin & 1977 \\
\hline & Ohlson & 1980 \\
\hline & Rose and Giroux & 1984 \\
\hline & Zavgren & 1985 \\
\hline & Gentry, Newbold, and Whiteford & 1985 \\
\hline & Lau & 1987 \\
\hline & Platt and Platt & 1990 \\
\hline & Koh & 1991 \\
\hline & Lynn and Wertheim & 1993 \\
\hline & Johnson and Melicher & 1994 \\
\hline & Barniv, Hathorn, Megrez, and Kline & 1999 \\
\hline & Lennox & 1999 \\
\hline \multirow{4}{*}{ Recursivepartitioningalgorithms (RPA) } & Marais, Patell, and Wolfson & 1984 \\
\hline & Frydman, Altman, and Kao & 1985 \\
\hline & Tam & 1991 \\
\hline & McKee and Greenstein & 2000 \\
\hline \multirow{14}{*}{ ArtificialNeuralNetworks (ANN) } & Odom and Sharda & 1990 \\
\hline & Sachenberger, Cinar, and Lash & 1992 \\
\hline & Coates and Fant & 1991-1992 \\
\hline & Tam and Kiang & 1992 \\
\hline & Coates and Fant & 1993 \\
\hline & Nittayagasetwat & 1994 \\
\hline & Serrano-Cinca & 1996 \\
\hline & Lee, Han, and Kwon & 1996 \\
\hline & Jo, Han, and Lee & 1997 \\
\hline & Serrano-Cinca & 1997 \\
\hline & Luther & 1998 \\
\hline & Zhang, $\mathrm{Hu}$, Patuwo, and Indro & 1999 \\
\hline & Yang, Platt, and Platt & 1999 \\
\hline & Shah and Murteza & 2000 \\
\hline
\end{tabular}

Source: Raei and Fallahpour (2004) 
Later, Beaver's model used on to measure the credit risk of bonds issued by companies. Probably the best known bankruptcy models creator is E. I. Altman's with his Z-score (Altman, 1968). This statistical model combines five financial ratios using multivariate discriminant analysis for purpose of forecasting failure in a diverse mix of entities. His pioneer study was based on a sample of 66 publicly traded, manufacturing companies. Altman's model had high predictive power for the initial sample one year before failure with accuracy amounting to $95 \%$.

Type I errors, those that predict a bankruptcy that does not occur, were shown for $6 \%$ of the companies analysed. Type II errors also were shown for $6 \%$ of the firms analysed. Type II errors predict a solvent firm that files bankruptcy (Altman, 1993). In 1980 Ohlson used log it analysis to develop a model to predict the health of companies (general application) with accuracy of $96 \%$ according to author. He worked with data sets obtained from 105 bankrupt companies and 202 non-bankrupt companies (Ohlson, 1980). Historical overview of model's creation is stated in table 1 .

The newest models are for example Ahn and Kim's hybrid case-based reasoning and genetic algorithm (Ahn \& Kim, 2009), the model based on the neural networks (Lee, Booth \& Alam, 2005), combination of random subspace approach and binary logit model (Li, Lee, Zhou \& Sun, 2011), hazard model based model (Shumway, 2001). The newest Czech models are bankruptcy index with accuracy 80.28\% (Karas \& Režnáková, 2014) and the model created using the sample of plastic producers and metal manufacturing companies with accuracy $90.96 \%$ (Homolka, Doležal \& Novák, 2014).

Some models are specialised in companies based for example on the branch, the company size or the specific business activity. For example, the models focused on the accommodation (hotels/lodging) (Youn \& Gu, 2010) (Kim, 2011), Internet companies (Chandra, Ravi, \& Bose, 2009), agriculture (Chrastinová, 1998) (Gurčík, 2002), manufacturing industry (Neumaierová, 2005), etc.

On the contrary, the prosperity models were created on thebasisof logicalassumptions without empiric research and these models do not have determined accuracy. For example the Grünwald's index (Grünwald \& Holečková, 2007), Doucha's Balance analysis I., II., III. (Doucha, 1996), Tamari risk index (Tamari, 1966) and Index of creditworthiness (see more Zalai, 2010) are concerned. The Czech index IN99 (Neumaierová 2002), based on which the financially healthy company is the company with positive economic value added, represents the exception.

\section{Kralicek's Q-test}

This test can be classified as a diagnostic model. This one-dimensional grading test was created in the year 1991 by the Austrian economist Peter Kralicek. It is mainly used in the German speaking countries under the name Quick test, Qtest or Kralicek's Fast Test. This model is different as with the increasing achieved value also the insolvency probability increases too. It uses the point evaluation (from 1 up to 5, like in the school) and is totally unique as in particular evaluated areas of the company economy (level of self-financing, duration of the debt payment, CF in \% of revenues, return on assets) it does not distinguish their importance, and thus it does not assign different weights. The resulting grade is the arithmetic average of ratings achieved in particular evaluated areas $\left(\left(Q_{1}+Q_{2}+Q_{3}+Q_{\mathbf{4}}\right) / 4\right)$. The company classified with the grade 1 and 2 is considered to be financially healthy, and the one with the grade 4 and 5 is pointed to the bankruptcy. See more in table 2.

Table 2: Evaluation scale of the Kralicek's Quick test

\begin{tabular}{|c|c|c|c|c|c|c|c|}
\hline \multirow{2}{*}{$\begin{array}{l}\text { Area of } \\
\text { analysis }\end{array}$} & \multirow{2}{*}{\multicolumn{2}{|c|}{ Ratios }} & \multicolumn{5}{|c|}{ Grades (evaluation scale) } \\
\hline & & & \multirow{2}{*}{$\begin{array}{c}1 \\
\text { Very good } \\
>30 \%\end{array}$} & \multirow{2}{*}{$\begin{array}{c}2 \\
\text { Good } \\
>20 \%\end{array}$} & \multirow{2}{*}{$\begin{array}{c}\begin{array}{c}3 \\
\text { Mid }\end{array} \\
>10 \%\end{array}$} & \multirow{2}{*}{$\begin{array}{c}4 \\
\mathrm{Bad} \\
<10 \%\end{array}$} & \multirow{2}{*}{$\begin{array}{c}5 \\
\text { Danger of } \\
\text { incolwance } \\
\text { negative }\end{array}$} \\
\hline \multirow{2}{*}{ 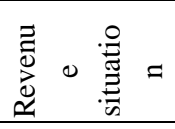 } & $\mathrm{Q}_{1}$ & Quota of equity & & & & & \\
\hline & $\mathrm{Q}_{2}$ & $\begin{array}{c}\text { Duration of debt payment from } \\
\text { CF }\end{array}$ & $<3$ years & $<5 \mathrm{y}$ & $<12 \mathrm{y}$. & $>12 \mathrm{y}$ & $>30 \mathrm{y}$ \\
\hline \multirow{2}{*}{ 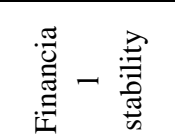 } & $\mathrm{Q}_{3}$ & Cash flow in $\%$ of revenues & $>10 \%$ & $>8 \%$ & $>5 \%$ & $<5 \%$ & negative \\
\hline & $\mathrm{Q}_{4}$ & Return on assets & $>15 \%$ & $>12 \%$ & $>8 \%$ & $<8 \%$ & negative \\
\hline
\end{tabular}

Source: Adapted according to (Kralicek, 1993) 
Today the original variant of the Quick Kralicek test, as well as its modified variant, can be used. Kuběnka states (Kuběnka, 2015) that the key difference in comparison with the original variant consists in the fact that values of partial indexes $\left(Q_{1}\right.$ up to $\left.Q_{\mathbf{4}}\right)$ are not compared with previously determined particular values for all branches, but are compared to percentiles of branch values.

\section{Methodology and Results}

In order to apply the Q-test on the analysed sample of companies it is necessary to calculate the values $Q_{\mathbf{1}}, Q_{\mathbf{2}}, Q_{\mathbf{3}}$, Q. stated in the Tab. 1. The used methodology of calculation is following:

a) Quota of equity $=$ equity $/$ assets

b) Duration of debt payment from $\mathrm{CF}=$ foreign capital/cash flow

c) Cash flow in \% from revenues $=$ cash flow/revenues

d) Profitability of assets $=$ EAT/total assets

e) Revenues $=$ Revenues from sold goods + Revenues from products and services

f) $\mathrm{CF}=$ according to (Kislingerová \& Hnilica, 2005) The economic results for the accounting period + depreciations + change of provision status.

Q-test uses grades but for the determination of the informative value capability of this model it is necessary to work with intervals. To divide the grading scale $\langle 1 ; 5\rangle$ in five intervals, the width 0,8 of point (grade) belongs to every interval. Then the intervals of evaluating scale are as follows:

a) Grade 1 with interval $<1 ; 1,8)$

b) Grade 2 with interval $<1,8 ; 2,6)$

c) Grade 3 with interval $<2,6 ; 3,4)$

d) Grade 4 with interval $<3,4 ; 4,2)$

e) Grade 5 with interval $\langle 4,2 ; 5\rangle$

Q-test was applied on the sample of financial data (for the year 2012) of 1504 companies from the Czech Republic, from the manufacturing industry (from CZ NACE 10 to CZ NACE 33). The data were taken from the database Magnus Web of the company Bisnode. The resulting values were compared to the financial situation of these companies at the end of the year 2013. The financial situation ofcompanywas derived from the achieved ROE level and from the verification of any symptomsoffinancial distress. The correct diagnostic consists in the situation when the Q-test evaluates the company with the grade 1 in the year 2012 and one year later, in 2013, ROE $>r_{e}$ (implicit costs of equity) and at the same time the company shows no symptoms of insolvency or negative equity. The correct diagnostic of the grade 2 is in the case when the analysed company achieves ROE $>r_{f}$ (risk-free rate) in one year and at the same time is shows no symptoms of distress. The correct diagnostic of the grade 3 is when $R O E_{2013}>0 \%$ (prosperity limits) is without bankruptcy symptoms. The correct diagnostic of the grade 4 is when $R O E_{2013}<0 \%$ (without symptomsofdistress) and the correct diagnostic of the grade 5 is in the case when the company shows symptoms ofdistress. According to the Ministry of Industry and Trade (MPO, 2014) ${ }^{r} f 2013$ is $2.26 \%$ and $r_{e} 2013$ is $12.11 \%$.

The ROE value was calculated based on financial statements (in 2013) of all companies and then compared with $r_{f}$ rate (risk-free rate) and $r_{e}$ rate (implicit costs of equity). The average value of ROE was $5.98 \%$ in analysed sample of companies, $R O E_{\max } \mathbb{E} 99.72 \%, R O E_{\min } \mathbb{R O E} \min -346.71 \%$, median of ROE was $9.74 \%$, $\sigma$ - standard deviation 47.46, variance of ROE 2254.42. In table3 are final frequencies of Q-test application and also results of ROE compared with $r_{f} \& r_{B}$ rates, critical limit $0 \%$ and checking symptoms of financial distress. 
Michal Kuběnka

Institute of Business Economics and Administration University of Pardubice, Pardubice City, Czech Republic

Table 3: Results of Q-test application vs. financial condition one year later

\begin{tabular}{|c|c|c|c|c|c|c|c|}
\hline Q-test 2012 rating & Evaluate scale & Frequency & Percent & $\begin{array}{c}\text { ROE \& distress } \\
\text { test }_{2013}\end{array}$ & $\begin{array}{c}\text { Evaluate } \\
\text { scale }\end{array}$ & Frequency & Percent \\
\hline Grade 1 <1;1.8) & Very good & 439 & $29.19 \%$ & $\begin{array}{c}\text { Grade } 1 . \\
\left(\mathrm{r}_{\mathrm{e}}>12.11 \%\right)\end{array}$ & Very good & 646 & $42.95 \%$ \\
\hline $\begin{array}{c}\text { Grade 2 } \\
<1.8 ; 2.6)\end{array}$ & Good & 358 & $23.80 \%$ & $\begin{array}{c}\text { Grade } 2 . \\
\left(\mathrm{r}_{\mathrm{f}}>2.26 \%\right)\end{array}$ & Good & 496 & $32.98 \%$ \\
\hline $\begin{array}{c}\text { Grade 3 } \\
<2.6 ; 3.4)\end{array}$ & Mid & 379 & $25.20 \%$ & $\begin{array}{c}\text { Grade 3 } \\
(\text { ROE }>0 \%)\end{array}$ & Mid & 126 & $8.38 \%$ \\
\hline $\begin{array}{c}\text { Grade 4 } \\
<3.4 ; 4.2)\end{array}$ & Bad & 239 & $15.89 \%$ & $\begin{array}{c}\text { Grade } 4 . \\
(\text { ROE }<0 \%)\end{array}$ & Bad & 222 & $14.76 \%$ \\
\hline \begin{tabular}{c} 
Grade 5 <4.2;5> \\
\hline $\mathrm{x}$
\end{tabular} & Insolvency & 89 & $5.92 \%$ & $\begin{array}{c}\text { Grade 5. } \\
(\text { distress })\end{array}$ & Insolvency & 14 & $0.93 \%$ \\
\hline $\mathrm{x}$ & 1504 & $100 \%$ & $\mathrm{x}$ & $\mathrm{x}$ & 1504 & $100 \%$ \\
\hline
\end{tabular}

\section{Source: Author}

Comparison of Q-test and ROE classification frequency is stated in Fig. 1. There is possible to observe quite different frequencies.

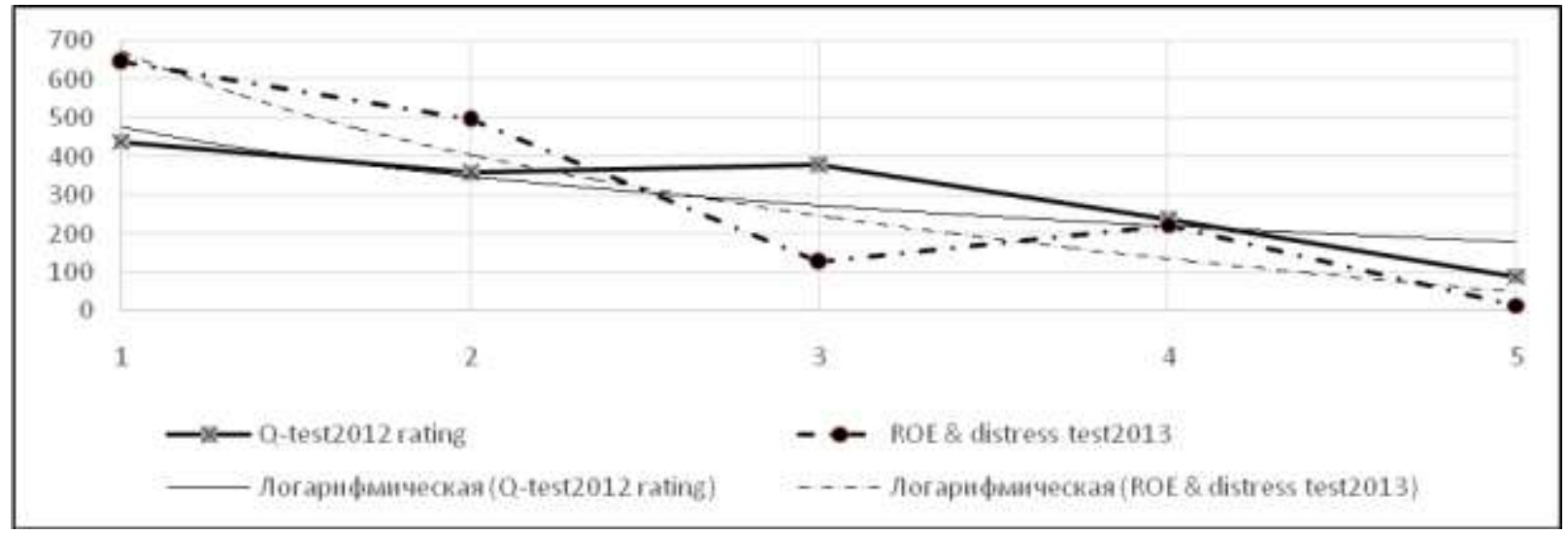

Figure 1: Classification frequency

Source: Author

Figure 2 illustrates in graphic form the differences between Q-test grades a ROE \& distress test grades. These differences take interval $\langle-4 ; 4\rangle$. Zero difference means completely correct diagnosis. Higher difference means lower informative value. It is seen that frequencies are normally distributed.

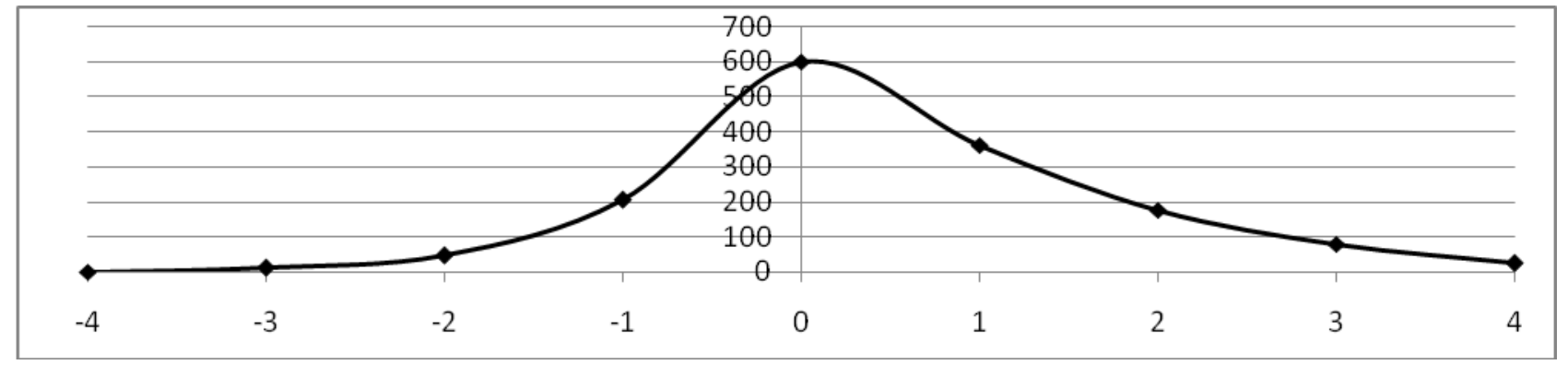

Figure 2: $Q$ test ${ }_{2012}$ vs. ROE $_{2013}$ fault freq.

Source: Author 
In figure 2 and also in table 4 is stated that Q-test grade meets the grade of ROE \& distress test absolutely in $39.89 \%$. If we are more benevolent and accept also the variation +/- 1 grade (in 5 degrees scale) informative value of Q-test is $77.59 \%$. In this case was stated informative value of Q-test on base of deviation quantification. See more in table 4 .

Table 4: Informative value of Q-test type A - based on quantification of deviation

\begin{tabular}{|c|c|c|c|c|c|}
\hline & $\begin{array}{c}\text { Q-test } \text { to12 }_{20} \text { rating } \\
\text { vs. } \\
\text { ROE \& distress test }{ }_{2013}\end{array}$ & Deviation & Frequency & \multicolumn{2}{|c|}{ In percent } \\
\hline \multirow{4}{*}{ 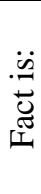 } & 4 degrees worse & -4 & 0 & \multicolumn{2}{|c|}{$0.00 \%$} \\
\hline & 3 degrees worse & -3 & 11 & \multicolumn{2}{|c|}{$0.73 \%$} \\
\hline & 2 degrees worse & -2 & 46 & \multicolumn{2}{|c|}{$3.06 \%$} \\
\hline & 1 degree worse & -1 & 205 & $13.63 \%$ & \multirow{3}{*}{$\sum 77.59 \%$} \\
\hline & Fact meets prediction & 0 & 600 & $39.89 \%$ & \\
\hline \multirow{4}{*}{ 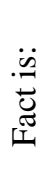 } & 1 degree better & 1 & 362 & $24.07 \%$ & \\
\hline & 2 degrees better & 2 & 177 & \multicolumn{2}{|c|}{$11.77 \%$} \\
\hline & 3 degrees better & 3 & 79 & \multicolumn{2}{|c|}{$5.25 \%$} \\
\hline & 4 degrees better & 4 & 24 & \multicolumn{2}{|c|}{$1.60 \%$} \\
\hline
\end{tabular}

Source: Author

Anotherwayhow to quantifytheinformativevalueof Q-test is to express numberofconsistentgrades. Table 5showsthat Qtest predict prosperity (grade 1 if ROE $>r_{e}$ ) in $48.30 \%$ and distress (grade 5 ) in $71.43 \%$.

Table 5: Informative value of Q-test type B - based on no. of correctly predicted grades

\begin{tabular}{|c|c|c|c|}
\hline Grades & $\begin{array}{c}\text { Frequency of grades Q- } \\
\text { test }_{\mathbf{2 0 1 2}}\end{array}$ & $\begin{array}{c}\text { Frequency of condition } \\
\text { One year later (2013) }\end{array}$ & $\begin{array}{c}\text { Correct prediction } \\
\text { (in \%) }\end{array}$ \\
\hline 1 & 312 & 646 & $48,30 \%$ \\
\hline 2 & 161 & 496 & $32,46 \%$ \\
\hline 3 & 43 & 126 & $34,13 \%$ \\
\hline 4 & 74 & 222 & $33,33 \%$ \\
\hline 5 & 10 & 14 & $71,43 \%$ \\
\hline Total & 600 & 1504 & $39,89 \%$ \\
\hline
\end{tabular}

Source: Author

However, this method is not suitable for comparison with other above mentioned models. This is because most of these models have three degrees (intervals) scale (e. g. (Karas\&Režnáková, 2014) and (Homolka, Doležal\&Novák, 2014)).

\section{Conclusion}

Prosperity models should measure financial condition of the companies above all in the area of creditworthiness and profitability. In contrast, bankruptcy models are not entirely different. All of bankruptcy models are predictive with one primary goal. The goal is to estimate, if analysed companies might go bankrupt or not in which case the situation is obvious. However, in case of prosperity models the answer is unclear. For example we might obtain information about a good financial health, however we do not know what exactly it means. It can be assumed that the analysed company will not be profitable while heading for bankruptcy. Often, detailed information on the level of profitability is needed. Unfortunately, there is no information available with most of the existing prosperity models relating to the interpretation of their results and to the accuracy of prosperity prediction.

Precisely this is the case of the Q-Test. It is difficult to establish whether we can ultimately rely on results of the Qtest's classification (e.g. with the probability of 75\%) or, on the contrary, whether the success rate of the model is too low (e.g. 10\%). That is why the author aimed to quantify the reliability of the Q-Test. For this purpose author's own 
methodology was created in order to evaluate financial situation of companies. This methodology was based on the achieved ROE value and on evaluating bankruptcy symptoms. Kralicek's Q-Test was chosen because it is one of Europe's well-known financial diagnostic models. This model determines the financial health of the company using financial analysis tools. Analysed company can obtain a final grade from 1 to 5 . Hence, this research focus was to quantify the relationship between the grade and ROE level. The analysis of 1504 companies brought interesting results that show that the Q-test has an informative value comparable to some bankruptcy models created using the mathematical-statistical analysis based on empiric data. The informative value of the Q-test was quantified for existing large and mid-size Czech companies with accuracy of $77.59 \%$ with the variation of one degree and up to $71.43 \%$ at the prediction of distress.

\section{Reference}

- Ahn, H., Kim, K. (2009), Bankruptcy prediction modeling with hybrid case-based reasoning and genetic algorithms approach,Applied Soft Computing, vol. 9, no. 2, pp. 599-607, CrossRef

- Altman, E. (1968), Financial ratios, discriminant analysis and the prediction of corporate bankrupcy. Journal of Finance, vol. 23, no. 4, pp. 589 - 609, $\underline{\text { CrossRef }}$

- Altman, E. (1993), Corporatefinancialdistress and bankruptcy, (3rd ed.), New York: John Wiley\&Sons, Inc.

- Beaver, W. H. (1966),Financialratios as predict or sof failure, JournalofAccountingResearch (Empirical Research in Accounting, Selected Studies), vol. 4, pp. 71-111.

- Chandra, D. K., Ravi, V., Bose, I. (2009), Failure prediction of dotcom companies using hybrid intelligent techniques, Expert Systems with Applications, vol. 36, no. 3, pp. 4830-4837, CrossRef

- Chrastinová, Z. (1998), Metódy hodnotenia ekonomic kejbonity a predik cie finanč nej situácie pol’no hospodárskych podnikov, Bratislava: VÚEPP.

- Fitzpatrick, P. J. (1931), Symptoms of industrial failures.Catholic University of America Press.

- Gurčík, L. (2002), G-index - the financial situation prognosis method of agricultural enterprises, Zemědělskáekonomika, vol. 48, no. 8, pp. 373-378.

- Homolka, L., Doležal, J., Novák, P. (2014),"Longitudinal Design as an Extension to Standard Banking Approaches to Companies' Financial Performance Assessment and Prediction", inEuropean Financial Systems 2014 proceedings of the 11th International Scientific Conference,Brno: Muni Press, pp. 236-243.

- Karas, M., Režňáková, M. (2014), Possibilities fot he Application of a Bankruptcy Prediction Model for Measuring Credit Risk of a Company, in Proceedings of Hradec Economic Days 2013, Hradec Králové: University of Hradec Králové, pp. 435-442.

- Kim, S. Y. (2011), Prediction of hotel bankruptcy using support vector machine, artificial neural network, logistic regression, and multivariate discriminant analysis. The Service Industries Journal, vol. 31, no. 3, 441468, CrossRef

- Kislingerová, E., Hnilica, J. (2005),Finančníanalýzakrokzakrokem. 1st. ed. Praha: C. H. Beck.

- Kralicek, P. (1993),Základyfinančníhohospodaření. 1st. ed. Praha: Linde.

- Kuběnka, M. (2015),Finančnístabilitapodniku a jejíindikátory. Pardubice: Univerzita Pardubice.

- Lee, K., Booth, D., Alam, P. (2005), A comparison of supervised and unsupervised neural networks in predicting bankruptcy of korean firms,Expert Systems with Applications, vol. 29, no. 1, pp. 1-16, CrossRef

- Li, H., Lee, Y., Zhou, Y., Sun, J. (2011), The random subspace binary logit (RSBL) model for bankruptcy prediction, Knowledge-Based Systems, vol. 24, no. 8, pp. 1380-1388, CrossRef

- Ministry of Industry and Trade - MPO, Financial analysis Retrived from http://www.mpo.cz/dokument150081.html (accessed 11 May 2016).

- Neumaierová, I. (2002),Výkonnost a tržníhodnotafirmy: metody, ukazatele, využití v praxi, 1st. ed. Praha: Grada Publishing.

- Neumaierová, I. (2005), Index IN05, inEuropean Financial Systems 2005 proceeding of the international conference, Brno: Masaryk University, pp. 143-148.

- Ohlson, J. (1980), Financialratios and theprobabilisticpredictionofbankruptcy,JournalofAccounting Research, vol 18, no. 1, pp. 109-131, CrossRef

- Raei, R., Fallahpour, S. (2004). Behavioral Finance, a DifferentApproach to the Financial Sphere. Journal of Financial Research, vol. 18, pp. 77-106. 


\section{Michal Kuběnka}

- Shumway, T. (2001), forecasting bankruptcy more accurately: A simple hazard model. Journal of Business, vol. 74, no. 1, pp. 101-124, $\underline{\text { CrossRef }}$

- Tamari, M. (1966), Financial ratios as a means of forecasting bankruptcy.Management International Review, vol. 6, no. 4, pp. 15-21.

- Youn, H., Gu, Z. (2010), Predicting Korean lodging firm failures: An artificial neural network model along with a logistic regression model,International Journal of Hospitality Management, vol. 29, no. 1, pp. 120-127, CrossRef

- Zalai, K. et. al. (2010),Finančno - ekonomickáanalýzapodniku, Bratislava: Sprint dva 